\title{
A Note on Dates, Spelling, and Names
}

Pe-revolutionary dates in this book are given in the "Old Style." In
conformity with academic practice, pre-revolutionary Russian orthography has been modernized. Transliterations follow the Library of Congress method, except where a common usage in English is well-established.

In the text I use "Sholom Aleichem." In notes, I refer to the famed writer with his name as spelled in the title page of the cited work; thus "Sholem Aleichem" also appears.

\section{List of Tables}

Table I: Kiev Population According to the 1897 Census

96

Table II: Jewish Population of Largest Cities

According to the 1897 Census 98

Table III: Budget of the Kiev Jewish Community for 1907 144 